\title{
Japan's Corporate Governance Structures and Credit Rating
}

\author{
Ahmed Zemzem (Corresponding author) \\ Dept. of Management, University of Sousse \\ Rue Khalifa El Karoui Sahloul - BP n 526 - 4002 Sousse, Tunisia \\ E-mail: ahz963@yahoo.fr \\ Samir Zouari \\ Dept. of Economics, University of Sousse \\ Rue Khalifa El Karoui Sahloul - BP n 526 - 4002 Sousse, Tunisia \\ E-mail: samir.zouari@yahoo.fr
}

Received: April 11, 2016 Accepted: May 15, $2016 \quad$ Published: June 1, 2016

doi:10.5296/ajfa.v8i1.9297 URL: http://dx.doi.org/10.5296/ajfa.v8i1.9297

\begin{abstract}
The aim of our research is to investigate whether good governance is associated with higher credit rating in Japanese firms. Mainly, this research seeks for the examination of the effect of governance attributes namely those related to the board and ownership structure also quality of information on credit ratings. Empirical analyses are conducted from a sample of 75 Japanese firms listed on Topix 100, over the period 2006- 2013 using Ordered Probit regression. The study shows that good governance is associated with higher credit rating and suggests that active monitoring by independent directors and better disclosure mitigate agency conflicts and protect the interests of debtholders.
\end{abstract}

Keywords: Credit rating, Board structure, Ownership structure, Transparency, Debtholders 


\section{Introduction}

First of all, we can say that there is a growing interest in corporate governance especially when many companies have experienced series of failures and frauds and suffered from losses. The resulting uncertainty has led to improved interest in corporate governance practices. One of the issues that have been raised is the presence of the agency problem which represents the existence of conflicts in the interests of managers and investors.

The presence of the agency problem usually distorts corporate policy choices and weakens corporate performance besides, it generates agency costs to control agents. Some ways to avoid these problems are to provide financial incentives as well as effective monitoring by independent directors also by improving transparency to create an appropriate environment.

Good governance is expected to reduce these problems, through its effective structures, to protect the interests of debtholders, to reduce the firm's cost debt and to result in higher credit rating. In fact, a wide literature has already been built to focus on these issues such as Aman and Nguyen (2013) and Ashbaugh-Skaife et al. (2006) by using US firms. But we build up our study using a sample of Japanese firms listed on Topix 100 from 2006 to 2013.

The results allow us to identify a significant relationship between credit rating and all governance attributes used in our study. Indeed, credit rating has a significant and negative relationship with larger board therefore smaller boards are better effective monitoring, similarly credit rating has negative relationship with higher insider ownership. This may be due to the confluence of opposite factors and to the negative entrenchment effect, in contrast credit rating has a significant and positive effect on independent board and transparency. Concerning control variables, the results show that credit rating is positively and significantly related to the firm size but negatively related to the leverage. So it's better to have a higher size of the firm and less leverage to improve better ratings.

The rest of the paper is structured as follows. Section 2 presents an overview of the credit rating mechanism. Section 3 presents literature review and hypotheses. Section 4 describes the research design. Findings will be discussed and summarized in Section 5. Finally, a conclusion and discussion are provided in Section 6.

\section{Credit Rating: An Overview}

The emergence of a credit rating as a mechanism that helps to reduce market information asymmetry in the financial markets has come from the times of the U.S. rail road companies in the mid-19th century. The fact that corporate started mobilizing resources directly from savers instead of accessing it through banks caused a credit risk that is why the need for an independent rating agency capable of evaluating creditworthiness of borrowers has appeared.

The study of the history of credit rating agencies may be divided into three distinct periods as mentioned by Lawrence (2013).

\subsection{The Beginnings}

The present-day credit rating industry has a lengthy history, beginning in the 19th century 
with financial publishing. The Mercantile Agency, one of the first credit reporting agencies, was established in 1841 by Lewis Tappan to ameliorate information asymmetries that probably lead to the financial crisis of 1837 . Then, in the 20th century, the emergence of Credit Rating Agencies (CRAs), when John Moody and Henry Poor started collecting financial and operating statistics on the railroad bond market and then selling this information to subscribers.

Credit ratings were first issued by Moody's Analyses Publishing Company in 1909, Moody's entry into the public bond rating business was followed by others: The Poor's Publishing Company in 1916; the Standard in 1922; and the Fitch Publishing Company in 1924.

\subsection{The 1930s Until The 1970s}

In the early 1930s, regulators of commercial banks began introducing the use of ratings for the required accounting practices of their banks. However, in 1936 there was regulatory change that required to regulate banks to use an investment grade to make bonds just as loans and investments to be safe rather than speculative which lead to the expand of the market for those CRAs's rating.

During the following decades, the state regulators of insurance companies also started to incorporate the major CRAs's ratings into their prudential regulation of their insurance companies. Also in 1975, the Securities and Exchange Commission (SEC) began using CRAs's ratings as the indicator of the riskiness of the bonds held by firms in their portfolios.

As a consequence, the SEC created a new category Nationally Recognized Statistical Rating Organization (NRSRO) and it certified Moody's, S\&P, and Fitch as NRSROs which would be the appropriate ones for the security firms to use in the determination of their needed capital.

In the late 1960s and early 1970s, the original business model adopted by John Moody in 1909 was progressively changed to a business model whereby the bond issuers were charged with the ratings and distributed to the general public at no charge but this new model created potential conflicts of interest.

\subsection{The 2000s Until 2010s}

In November 2001, with the bankruptcy of the Enron Corporation, a considerable amount of media focused big attention on CRAs because Enron's bonds had been rated as "investment grade" by all three major CRAs until five days before the bankruptcy. This situation made $C R A s$ in a difficult position, indeed congressional asked the CRAs why they were so slow to recognize Enron's weakened financial condition and the SEC was asked about the NRSRO system, how the SEC managed it, and why there were only three certified NRSROs? As a consequence, the SEC tried to make some changes by certifying additional NRSROs which got up to ten NRSRO in 2013.

Even if rating agencies have experienced some difficulties during few years and have been harshly criticized, they remain a key mechanism in financial markets. 


\section{Literature Review and Hypotheses}

We start this section by explaining the effect of governance structures on corporate decisions and then we will examine the effect of governance structures on credit ratings through a series of hypotheses.

\subsection{The Effect of Governance Structures on Corporate Decisions}

The agency problem inherent in the separation of ownership and control of assets has occurred since the 18th century by Adam Smith in his Wealth of Nations, and in other studies such as those by Berle and Means (1934) and Lorsch and Maclver (1989). The agency literature underlines a number of conflicting preferences. Indeed, when principal (shareholders) delegates some decision-making responsibility to agents (manager). The latter may make decisions that conflict with the best interests of the shareholders.

The divergence of interests between principals and agents lead supporters of agency theory to specify some mechanisms for reducing agency losses (Eisenhardt 1989). These mechanisms include incentive schemes for managers by obtaining shares perhaps at reduced price or receiving shares based on the company's performance. Another form of managerial compensation is the cash bonus and according to Jensen and Murhpy (1990) this cash bonus is a variable sum of money the $C E O$ gets above his fixed salary, if he meets the targets of the shareholders. But money alone cannot often induce agents to act in the interests of the principal. There is intrinsic motivation that can be harnessed in solving agency problems by examining ways to improve non-pecuniary motivation.

Another solution to mitigate agency problems is monitored by the board of directors which is considered as key purpose to ensure the company's continued growth and prosperity. The role of the board of directors is to act for the best interests of the company (shareholders and stakeholders). Also we have shareholders monitoring which is considered as a mechanism that helps to reduce agency costs. Demsetz (1983) and Shleifer and Vishny (1986) propose that the existence of large shareholders leads to better monitoring of managers.

In fact, producing information and making it accessible to all stakeholders may reduce information asymmetries and mitigate the associated agency conflicts. This can help decrease incidents of skewed decision making, improving planning and formulation of strategy, and facilitating effective evaluation of past performance (Yaron and Manos 2010).

Good governance will try to mitigate these agency conflicts by previous solutions to guarantee the interest of investors and this brings us to study governance structures and their effect on credit ratings.

\subsection{Hypotheses Development}

To begin with, we can say that prior studies on corporate governance have focused on one attribute "board independence", but the results from these studies were limited (Ashbaugh-Skaife et al. 2004). Since 2002, as research has been developed, they have become four attributes ownership structure and influence, financial stakeholder's rights and relations, financial transparency and disclosure, and board structure and processes (Standard 
\& Poor's 2002). Based on these attributes good governance can reasonably be expected to mitigate agency problems, to reduce the risk to debtholders, to decrease the firm's cost of debt and consequently higher credit ratings.

\subsubsection{Board Structure}

Board of directors has two essential functions which are advising and monitoring (Raheja 2005; Adams and Ferriera 2007). The Advisory function involves the provision of expert advice to the CEO and access to critical information and resources (Fama and Jensen 1983) performed by both insiders and Outsiders. And the monitoring role involves monitoring company performance and reduce agency costs.

Many economic research has been interested in the board size, some of them have agreed that larger boards are more effective due to the fact that an increasing number of non-executive directors provides more information (Lehn et al. 2004) and leads to higher performance (Dalton and Dalton 2005). Also increasing board size may avoid the idea of choosing a risky project because it has to be accepted by all members. Then the quality decision of a larger group is better (Sah and Stiglitz 1991).

Some other studies interested with the benefits of larger boards, in fact (Upadhyay 2015) found that larger boards enjoy a better credit rating which indicates to lower default risk and hence greater bond valuation. Despite the fact that larger board has positive effect on firm's performance and thus on credit rating some other researchers found that smaller boards are more effective to mitigate agency problems due to the fact that when boards become larger the skills of directors are reduced and the agency costs will therefore increase, also coordination problems will appear because more board members will lead to more conflicts and disagreement in taking decision as explained by Yarmack (1996) and Eisenberg et al. (1998) as well as the occurrence of problems relating to processes of making decision will appear (Conyon and Peck 1998).

With the balance of the arguments above, we suggest the following hypothesis:

H1: Firms with larger boards are associated with higher credit rating.

An emerging strand of literature highlights on the effect of the composition of the board of directors and the importance of the percentage of independent outside directors on the performance of the firm and therefore their effect on credit ratings. Boards dominated by outsiders are arguably in a better position to monitor and control managers (Dunn 1987).

Outside directors are independent of the firm's managers, and in addition bring a greater breadth of experience to the firm (Firstenberg and Malkiel 1980). Also through their firm and industry specific experience, outside directors become valuable advisors in strategic decision making (Kor and Sundaramurthy 2009). Bhojraj and Sengupta (2003) found that firms with an independent board have a positive effect on credit ratings and contribute to decrease the cost of debt of US firms.

Traditionally, the boards of directors of most listed companies in Japan have been composed solely of insiders, with the number of board members tending to be large by international 
standards. Even recently in 2010, less than half of Japanese firms listed on the first section of the Tokyo Stock Exchange had outside directors. However, the number of outside directors on Japanese boards has increased dramatically since 2010 up to $62.2 \%$ in 2013 and the trend is expected to continue (Jeff and Hisateru 2014).

Based on the above arguments, our second hypothesis is:

H2: Firms with higher proportion of outside directors are associated with higher credit rating.

\subsubsection{Ownership Structure}

The issue of insider ownership and agency problem has long been an interest in many researchers due to its impact on firms' value and monitoring of management investment activities.

On the one hand, higher insider ownership can help align the interests of management and shareholders and improves disclosure quality (Han et al. 2013) and on the other hand, Morck et al. (1988) argue that higher insider ownership would provide managers with deeper entrenchments and, therefore, greater scope for opportunistic behavior indeed, it increases the power of managers and allows them to thwart the monitoring of shareholders (Demsetz 1983) which may be a concern for debtholders, also it may lead to the diversion of funds and then causes a lower efficiency (Jensen and Meckling 1976; Morck et al. 1988).

With the balance of the arguments above, we suggest the following hypothesis:

H3: Firms with higher insider ownership are associated with higher credit ratings.

\subsubsection{Financial Transparency and Disclosure}

Many researchers have considered that information asymmetry as another reason for agency problems indeed, Klein et al. (2002) observe that, "in corporate finance, asymmetric information refers to the notion that firm insiders, typically the managers, have better information than do market participants on the value of their firm's assets and investment opportunities" and this results in an agency problem.

Shareholders, as principals, attempt to reduce agency problems and asymmetric information by changing the behavior of the manager through incentives such as bonuses and effective monitoring to improve long-term performance. Lee et al. (2008) found that timely disclosure (quality disclosure) reduces information asymmetry and enhance the trust between managers and shareholders. Consequently, shareholders will be more willing to invest in the company, thereby decreasing the cost of capital. Also Sengupta (1998) underlined that disclosure quality reduces the cost of debt because lenders considered high quality disclosure as having a lower likelihood of withholding unfavorable information.

Regarding the advantages and the benefits of greater transparency, we suggest the following hypothesis:

H4: Firms with greater transparency are associated with higher credit ratings. 


\section{Research Methodology}

\subsection{Sample Selection and Data Sources}

We collect data relating to Japanese firms listed on Topix 100 which represents an important stock market index for the Tokyo Stock Exchange (TSE) in Japan. Since data are not available, the study will be based only on 75 companies during 2006-2013. Long-term credit ratings were handed collected from reports published by Rating and Investments Information (R\&I)) and the leading credit rating agency in Japan.

Firms are rated according to a well-determined scale (AAA, AA, A, BBB, BB, B) with AAA represents the highest grade and as follows to Bhojraj and Sengupta (2003) the letter is transformed into numerical values (from 1 to 6 ) and the safest firm obtains the highest value.

To improve our results and to reduce the occurrences of insufficient observations, we group firms into rating categories without consideration of notches (- or + ). For example, our set of AA firms includes those with $\mathrm{AA}^{+}, \mathrm{AA}$ and $\mathrm{AA}^{-}$ratings. The explanatory variables and the control variables are collected from Orbis Database.

\subsection{Variables Measurement}

Governance variables are classified in three groups: The first one represents the firm's board structure and it consists of board size which is measured by the number of directors and board independence calculated by the number of outside directors. In fact, many studies are based on these variables to determine the importance of the board of directors to improve performance and to ensure the company's prosperity.

The second group is an ownership structure and it consists of one variable. Insider ownership measured by the proportion of shares owned by employees, directors ..., this variable is equivalent to managerial ownership. Ownership structures have also a significant importance in corporate governance because they affect their incentives of managers, and thereby the efficiency of firms.

The third group represents the quality of information available to investors. It consists of one variable which is the timeliness of the firm's disclosure and represents the number of days the firm takes to release its annual statements after the fiscal year-end. We define this variable as the same way calculated by Aman and Nguyen (2013) but we use the date of the end of the fiscal year instead of the date of the closure of the accounts: the maximum value (60 days) minus the number of days the firm is taking to release its annual statements after the fiscal year-end.

Since the governance variables are strongly correlated, they may create multicollinearity problems in the regressions. To mitigate this concern, we collapse the governance variables into a single factor using Principal Component Analysis (PCA). The untabulated results (available upon request) show that one of four components happen to exhibit eigenvalues higher than one (1.405106). Then we look out to the variance. After that, we focus on the factor, called "governance score", which accounts for $46.84 \%$ of the total variance. 
We also use some firm characteristics as control variables such as Andrea et al. (2007) who argued that the most significant variables in explaining ratings were size, financial leverage, profitability and volatility; and supported the idea that the higher is financial leverage and the higher is the volatility the worst is the rating.

Firm size is proxied by the natural log of total assets and it is included as a control variable because larger firms face lower risk by having greater opportunities to diversify their risks across a wider range of products and markets, and thus are expected to have higher credit ratings Ashbaugh-Skaife et al. (2006). Bhojraj and Sengupta (2003) and Bradley and Chen (2011) indicate that firm size has a significantly positive influence on credit ratings and highly significant effect on the cost of debt. Similarly, Anderson et al. (2004) examine the relation between board size and the cost of debt financing and they find that firm with large size enjoy a lower cost of debt because lenders think that these companies are being monitored more effectively by a diversified portfolio of experts. Moreover, as size increases, firms are allowed by financial intermediaries such as banks to invest more in a new project and thus will improve performance, and if large firms face financial problems, they can easily solve them by selling more assets.

In addition, as follows to Ashbaugh-Skaife et al. (2006) and Aman and Nguyen (2013) financial leverage is measured by the ratio of debt to total capital. Increasing a firm's leverage affects the cost of debt financing and may imply a lower credit rating. Bhojraj and Sengupta (2003) confirm this prediction using the debt-to-equity ratio to measure leverage and to explore the effects of corporate governance in debt ratings and cost of debt financing. Darren (2006) was interested in higher credit rating and the benefits that can provide to the firm and in this context he showed that firms depend on the level of leverage to upgrade their rating especially those with lower level and for those with upper range of ratings, they also depend on the leverage to avoid downgrades. Ashbaugh-Skaife et al. (2006) based on the leverage in their studies regarding the effects of corporate governance on firms 'credit ratings as one of the firm-specific control variables considering the fact that it has significant effects on credit ratings.

Also, profitable firms attract more investors and enjoy a sustainable competitive advantage. Profitability is proxied by the Return on Assets ratio (ROA), and is calculated by the firm's average operating profits over total assets over the last three years to smooth out annual fluctuations. Bhojraj and Sengupta (2003) showed that lower performing firms are associated with higher levels of default risk and profitability is associated with significantly higher ratings in the US. Hung et al. (2013) showed in their study about what factors affect credit rating that as profitability increase probabilities of receiving higher ratings are expected to increase thus consistent with prior research credit ratings are positively related profitability.

The final one is firm risk which has been proxied by the volatility of stock returns over the past 5 years. This volatility is measured by the standard deviation of monthly stock returns including dividends. One popular approach to assessing credit risk that involves Merton's (1974) model suggests that stock volatility increases the risk of default. Bradley and Chen (2011) showed that higher stock volatility is associated with lower credit ratings and higher 
credit spreads. Anderson et al. (2004) also found that stock volatility significantly increases yield spreads.

\subsection{Model Research}

Because of the discrete and ordering nature of the dependent variable in this study, Ordinary Least Squares (OLS) regression will be an inappropriate model (Yang and Raehsler 2005). Therefore, we follow Amato and Furfine (2004) and Aman and Nhuyen (2013) by using the Ordered Probit model in our empirical analysis:

$$
\begin{aligned}
& \text { CRating }_{i t}=\alpha_{0}+\alpha_{1} \text { BSize }_{i t}+\alpha_{2} \text { OutDr }_{i t}+\alpha_{3} \text { IOwn }_{i t}+\alpha_{4} \text { Timeliness }_{i t}+\alpha_{5} \text { GScore }_{i t}+\alpha_{6} \\
& \text { FSize }_{i t}+\alpha_{7} \text { Leverage }_{i t}+\alpha_{8} \text { ROA }_{i t}+\alpha_{9} \text { Volatility }_{i t}+\varepsilon_{i t}
\end{aligned}
$$

Where CRating is the value corresponding to the long-term rating given by R\&I, BSize is the number of directors on the board, OutDr is the number of outside directors on the board, IOwn is the proportion of shares owned by employees, directors ..., Timeliness is the maximum value (60 days) minus the number of days the firm takes to release its annual statements after the fiscal year-end, GScore is the governance score as described above, FSize is the natural log of total assets, Leverage is total debt over total assets, $R O A$ is operating income over total assets and Volatility is the standard deviation of stock returns over the last 60 months.

\section{Empirical Results}

\subsection{Descriptive Statistics}

Table 1 reports descriptive statistics for our measures of credit rating, governance variables, and firm characteristics as control variables.

The table shows that operating profitability $(R O A)$ is on average $3.5 \%$ with a narrow interquartile range of $1.65 \%$ and $5.22 \%$. Stock return is also distributed over a narrow range of $0.894 \%$ and $3.688 \%$. Among the governance variables, the average board size (BSize) consists of 12.7 directors. The average of outside directors (OutDr) is $2.2 \%$ with a median of $2 \%$ and this proportion is a little low reflects the fact that Japanese firms improve gradually their board by increasing the proportion of outside directors because Japanese boards have been always controlled by insiders (Aman and Nguyen 2013).

The average of insider ownership (IOwn) is $9.19 \%$ with a narrow range interquartile of $3.81 \%$ and $13.36 \%$. The timeliness variable indicates that firms taken average 54.2 to release their annual statements $(60-5.8=54.2)$. The average rating of 4.711 indicates that ratings are centered between "A" and "AAA". This led us to conclude that Japanese firms in our sample have improved their ratings over the period of $2006-2013$. 
Table 1. Sample descriptive statistics

The table reports descriptive statistics of all variables used in the current study.

\begin{tabular}{|l|l|l|l|l|l|l|l|l|}
\hline & Mean & S. D. & Q1 & Median & \multicolumn{1}{|c|}{ Q3 } & Skewness & Kurtosis & N \\
\hline $\begin{array}{l}\text { Rating variable: } \\
\text { - CRating } \\
\text { Governance } \\
\text { variables: }\end{array}$ & 4.711 & 0.564 & 4 & 5 & 5 & -1.100 & 4.192 & 461 \\
- BSize & 12.703 & 7.547 & 9 & 13 & 14 & 1.611 & 8.891 & 529 \\
- OutDr & 2.213 & 1.890 & 0 & 2 & 4 & 0.554 & 2.796 & 529 \\
- IOwn & 9.194 & 6.969 & 3.81 & 6.695 & 13.36 & 0.953 & 2.977 & 186 \\
- Timeliness & 5.814 & 17.334 & 0 & 0 & 0 & 2.735 & 8.609 & 538 \\
- GScore & 0.070 & 1.180 & -0.57 & 0.213 & 0.880 & -0.357 & 2.658 & 126 \\
Firm characteristics: & & & & & & & & \\
- FSize & 7.413 & 0.374 & 7.143 & 7.399 & 7.671 & 0.151 & 2.653 & 531 \\
- Leverage & 107.8 & 97.88 & 36.43 & 79.73 & 146.38 & 1.642 & 6.115 & 530 \\
- ROA & 3.504 & 3.173 & 1.65 & 3.22 & 5.22 & -0.220 & 7.472 & 531 \\
- Volatility & 3.052 & 4.301 & 0.894 & 1.811 & 3.688 & 5.752 & 53.006 & 530 \\
\hline
\end{tabular}

Notes: CRating is the value corresponding to the long-term rating given by R\&I, BSize is the number of directors in the board, OutDr is the number of outside directors in the board, IOwn is the proportion of shares owned by employees, directors..., Timeliness is the maximum value (60 days) minus the number of days the firm takes to release its annual statements after the fiscal year-end, GScore is the governance score as described above, FSize is the natural log of total assets, Leverage is total debt over total assets, $R O A$ is operating income over total assets and Volatility is the standard deviation of stock returns over the last 60 months.

\subsection{Correlation Matrix}

To verify the absence of multicollinearity problems, we use the correlation matrix for the independent variables which can be found in Table 2 .

The examination of the correlation coefficients allows us to study the null hypothesis of no correlation between explanatory variables. We consider 0.8 as the limit value of the correlation coefficient, which corresponds to the limit set by Kennedy (1985), to confirm the null hypothesis. Hence, if correlation between two variables exceeds 0.8 , we have to reject the null hypothesis and we start having serious problems of multicollinearity.

In our case, the correlation matrix shows that all coefficients are below 0.8 . We can conclude, then, in the absence of multicollinearity between the explanatory variables. So, the problem of multicollinearity does not seem critical, and thereafter, all variables in our study can be accepted. 
Table 2. Correlation matrix

The table presents the pairwise correlations between key regressor variables by using Pearson's correlation coefficients.

\begin{tabular}{|l|l|l|l|l|l|l|l|l|l|l|}
\hline & & \multicolumn{1}{|c|}{1.} & \multicolumn{1}{c|}{2.} & 3. & 4. & 5. & 6. & 7. & 8. & 9. \\
\hline 1. & BSize & 1 & & & & & & & & \\
\hline 2. & OutDr & 0.155 & 1 & & & & & & & \\
\hline 3. & IOwn & 0.002 & 0.039 & 1 & & & & & & \\
\hline 4. & Timeliness & -0.173 & 0.046 & 0.009 & 1 & & & & & \\
\hline 5. & GScore & 0.757 & 0.791 & 0.374 & 0.000 & 1 & & & & \\
\hline 6. & FSize & 0.079 & 0.162 & -0.147 & -0.065 & 0.046 & 1 & & & \\
\hline 7. & Leverage & -0.168 & -0.044 & -0.191 & -0.126 & -0.131 & 0.511 & 1 & & \\
\hline 8. & ROA & 0.038 & 0.003 & 0.228 & 0.050 & 0.160 & -0.334 & -0.447 & 1 & \\
\hline 9. & Volatility & 0.016 & -0.011 & 0.073 & -0.0495 & -0.052 & -0.070 & 0.021 & 0.187 & 1 \\
\hline
\end{tabular}

Notes: BSize is the number of directors in the board, OutDr is the number of outside directors in the board, IOwn is the proportion of shares owned by employees, directors..., Timeliness is the maximum value (60 days) minus the number of days the firm takes to release its annual statements after the fiscal year-end, GScore is the governance score as described above, FSize is the natural log of total assets, Leverage is total debt over total assets, $R O A$ is operating income over total assets and Volatility is the standard deviation of stock returns over the last 60 months.

\subsection{Regression Analysis of Credit Rating on Governance Variables}

In order to investigate whether corporate governance has an effect on credit ratings we use a series of Ordered Probit models with panel data and in which the dependent variable is the firm's credit rating and the explanatory variables are the firm's governance attributes. Also we utilize unbalanced panel because we have some missing dataset. This method was inspired by the study of Aman and Nguyen (2013).

We use model 1 to identify whether larger boards are associated with higher credit rating. Model 2 is associated with the ownership structure. Model 3 is used to identify whether transparency and the information provided to investors are associated with higher credit rating. Model 4 regroups all the individual governance variables that are included in the regression to evaluate their ability to provide explanatory power beyond what the other governance (and control) variables already explain, and model 5 is based on the aggregate score calculated by Principal Component Analysis (PCA). 
Table 3. Ordered Probit regression of credit rating on governance variables

The table reports the results from regressions in panel data. The use of a robust option for estimating the standard errors is based on a Breusch-Pagan test for heteroscedasticity; $\mathrm{t}$-Statistics are reported in parentheses.

\begin{tabular}{|c|c|c|c|c|c|}
\hline \multicolumn{6}{|c|}{ Dependent variable: CRating } \\
\hline Variables & Model 1 & Model 2 & Model 3 & Model 4 & Model 5 \\
\hline \multicolumn{6}{|l|}{ Governance variables: } \\
\hline \multirow[t]{2}{*}{ - $\quad$ BSize } & -0.0081944 & & & $-0.046278^{*}$ & \\
\hline & $(-0.68)$ & & & $(-2.16)$ & \\
\hline \multirow[t]{2}{*}{ - $\quad$ OutDr } & $0.0743726^{*}$ & & & 0.0915511 & \\
\hline & $(2.21)$ & & & $(1.49)$ & \\
\hline \multirow[t]{2}{*}{ - IOwn } & & 0.2273908 & & $-0.03164 * *$ & \\
\hline & & $(-1.60)$ & & $(-1.67)$ & \\
\hline \multirow[t]{2}{*}{ - $\quad$ Timeliness } & & & $-0.464515^{*}$ & 0.3676142 & \\
\hline & & & $(-2.82)$ & $(1.40)$ & \\
\hline \multirow[t]{2}{*}{ - GScore } & & & & & -0.0764576 \\
\hline & & & & & $(-0.64)$ \\
\hline \multicolumn{6}{|l|}{ Firm characteristics: } \\
\hline \multirow[t]{2}{*}{ - FSize } & $1.125332 *$ & $1.146093 *$ & $1.279802 *$ & $1.218704 *$ & $1.248876^{*}$ \\
\hline & $(4.67)$ & $(3.15)$ & ( 5.93) & $(3.45)$ & $(2.68)$ \\
\hline \multirow[t]{2}{*}{ - Leverage } & $-0.006933^{*}$ & $-0.006338^{*}$ & $-0.00809^{*}$ & $-0.008017^{*}$ & $-0.006236^{*}$ \\
\hline & $(-6.83)$ & $(-3.85)$ & $(-7.83)$ & $(-4.26)$ & $(-3.61)$ \\
\hline \multirow[t]{2}{*}{ - $\quad R O A$} & -0.0124177 & -0.0120545 & $-0.059581^{*}$ & -0.0079655 & 0.0030887 \\
\hline & $(-0.42)$ & $(-0.25)$ & $(-2.20)$ & $(-0.16)$ & $(0.06)$ \\
\hline \multirow[t]{2}{*}{ - Volatility } & 0.0607296 & $0.2273908^{*}$ & $0.098029 *$ & 0.1182618 & $0.320123^{*}$ \\
\hline & $(1.36)$ & $(2.67)$ & $(2.75)$ & $(1.46)$ & $(2.29)$ \\
\hline Wald statistic & $60.78^{*}$ & $24.52 *$ & $69.54 *$ & $54.51^{*}$ & $21.50^{*}$ \\
\hline Pseudo $\mathrm{R}^{2}$ & 0.0933 & 0.1140 & 0.1105 & 0.1406 & 0.1132 \\
\hline $\mathrm{N}$ & 394 & 154 & 395 & 146 & 110 \\
\hline
\end{tabular}

Notes: CRating is the value corresponding to the long-term rating given by R\&I, BSize is the number of directors in the board, OutDr is the number of outside directors in the board, IOwn is the proportion of shares owned by employees, directors..., Timeliness is the maximum value (60 days) minus the number of days the firm takes to release its annual statements after the fiscal year-end, GScore is the governance score as described above, FSize is the natural log of total assets, Leverage is total debt over total assets, $R O A$ is operating income over total assets and Volatility is the standard deviation of stock returns over the last 60 months; *significance at the $5 \%$ level; **significance at the $10 \%$ level.

These results indicate that the overall model is statistically significant ( $\mathrm{P}$-value $<5 \%$ ). To start with model 1 , the coefficient of board size is negative and not significant. In contrast the coefficient of outside directors is positive and significant at the $5 \%$ and this result reveals that 
outside directors have a positive effect on credit rating. Therefore, independent boards are associated with higher credit rating and this finding is consistent with Bhojraj and Sengupta (2003), they found that firm with independent board has a positive effect on credit ratings and contributes to decrease the cost of debt of US firms.

The regression in model 2 shows that the coefficient of insider ownership which refers to ownership structure is positive but not significant. It indicates that insider ownership has no effect on credit rating. This lack of effect may be due to the confluence of opposite factors because on the one hand, greater stock ownership may provide insider more incentives to make more effort and manager the firm more effectively. On the other hand, this increases their entrenchment effect which is detrimental to debtholders and this result is consistent with Aman and Nguyen (2013).

We focus now on Model 3, the coefficient representing the quality of information is negative and significant at the 5\% level using P-value. This result may be due to the fact that these companies take more time to release its annual statements and this will lead to decrease the rating.

As for model 4, the coefficient of board size becomes significant but negative which reveals that higher credit rating is associated with smaller boards. This result may due to the fact that smaller boards are more effective and have better monitoring which is consistent with Eisenberg et al. (1998) who found that when boards become larger agency problems tend to arise. Insider ownership becomes significant with negative coefficient. Therefore, higher credit rating is associated with less insider ownership due to their entrenchment effect. In contrast outside directors and timeliness are positive but not significant.

Governance score in model 5 is not significant. This result is inconsistent with Aman and Nguyen (2013) due to the fact that we don't use the same number of items given the lack of data.

As for control variables, leverage have a negative and significant effect on credit rating in all models so increasing a firm's leverage affect the cost of debt financing and may imply a lower credit rating which is consistent with Bhojraj and Sengupta (2003). Firm size has a positive and significant effect on rating, therefore larger firms have greater opportunities to diversify their risks across a wider range of products and markets, and thus are expected to have higher credit ratings as mentioned by Shbaugh-Skaife et al. (2006).

\section{Conclusion}

The aim of our research is to investigate whether corporate governance has an effect on credit ratings through an empirical study of a sample of 75 Japanese firms listed in Topix 100 during the period 2006-2013 and using panel data analysis method and Ordered Probit model.

Our finding is consistent with some other researches. Indeed, we find that firms with higher proportion of outside directors are associated with higher credit rating due to the importance of independent board to protect the interests of debtholders. And for size of the board we find 
that higher credit rating is associated with smaller firms which are more effective due to the fact that these firms may mitigate agency problem by reducing their boards and this is consistent with Eisenberg et al. (1998). Higher insider ownership has a negative effect on credit rating because of the confluence of opposite factors especially their negative entrenchment effect. Many researches have approved that timeliness has a positive effect on credit rating. Indeed, timely disclosure (quality disclosure) reduces information asymmetry and therefore mitigate agency problems but in our sample we find that companies take more time to circulate their information so they have a problem of information asymmetry.

This paper provides directions for future research by introducing more other explanatory variables to make it more significant. In addition, the study that we conduct should be considered as a preliminary to a more complete study on a larger sample.

\section{References}

Adams, R.B., \& Ferreira, D. (2007). A theory of friendly boards. Journal of Finance, 26, 217-250. http://dx.doi.org/10.1111/j.1540-6261.2007.01206.x

Aman, H., \& Nguyen, P. (2013). Does a good governance matter to the debtholders? Evidence from the credit rating of Japanese firms. Research in International Business and Finance, 11, 425-444. http://dx.doi.org/10.1016/j.ribaf.2013.02.002

Amato, J.D., \& Furfine, C.H. (2004). Are Credit Ratings Procyclical? Journal of Banking and Finance, 28, 2641-2677. http://dx.doi.org/10.1016/j.jbankfin.2004.06.005

Anderson, R., Mansi, S., \& Reeb, D. (2004). Board characteristics, accounting report integrity, and the cost of debt. Journal of Accounting and Economics, 37, 315-342. http://dx.doi.org/10.1016/j.jacceco.2004.01.004

Andrea, M.A.F., Minardi, A.Z.S., \& Rinaldo, A. (2007). A Methodology for estimating credit rating and the cost of debt for business units and privatelyheld companies. Credit Scoring Conference, the Credit Research Center, United Kingdom.

Ashbaugh, H., Collins, D., \& LaFond, R. (2004). The Effects of Corporate Governance on Firms' Credit Ratings. Working paper, University of Iowa.

Ashbaugh-Skaife, H., Collins, D., \& LaFond, R. (2006). The effects of corporate governance on firm's credit ratings. Journal of Accounting and Economics, 42, 203-243. http://dx.doi.org/10.1016/j.jacceco.2006.02.003

Berle, A.A., \& Means, G.C. (1934). The Modern Corporation and Private Property, New York: The Macmillan Company.

Bhojraj, S., \& Sengupta, P. (2003). The effect of corporate governance on bond ratings and yields: the role of institutional investors and outside directors. The Journal of Business, 76, 455-475. http://dx.doi.org/10.1086/344114 
Bradley, M., \& Chen, D. (2011). Corporate governance and the cost of debt: evidence from director limited liability and indemnification provisions. Journal of Corporate Finance, 17, 83-107. http://dx.doi.org/10.1016/j.jcorpfin.2010.08.001

Conyon, M.J., \& Peck, S.I. (1998). Board size and corporate performance: evidence from European countries. The European Journal of Finance, 4, 291-304. http://dx.doi.org/10.1080/135184798337317

Dalton, D., \& Dalton, C.R. (2005). Boards of directors: Utilizing empirical evidence in developing practical prescriptions. British Journal of Management, 16, S91-S97. http://dx.doi.org/10.1111/j.1467-8551.2005.00450.x

Darren J. K. (2006). Credit Ratings and Capital Structure. The Journal of Finance, 61, 1035-1072. http://dx.doi.org/10.1111/j.1540-6261.2006.00866.x

Demsetz, H. (1983). The structure of ownership and the theory of the firm. Journal of Law and Economics, 26, 375-390. http://dx.doi.org/10.1086/467041

Dunn, D. (1987). Directors aren't doing their jobs. Fortune, 117-119.

Eisenberg, T., Sundgren, S., \& Wells, M.T. (1998). Larger Board size and decreasing firm value in small firms. Journal of Financial Economics, 48, 35-54. http://dx.doi.org/10.1016/S0304-405X(98)00003-8

Eisenhardt, K.M. (1989). Agency theory: An assessment and review. Academy of management review, 14, 57-74.

Fama, E., \& Jensen, M. C. (1983). Separation of ownership and control. Journal of Law and Economics, 26, 301-326. http://dx.doi.org/10.1086/467037

Firstenberg, P., \& Malkiel, B. (1980). Why corporate boards need independent Directors. Management review. Management review, 69, 26-38.

Han, S., Kang, T., Jin, J.Y., \& Lobo, G.J. (2013). Managerial Ownership and Financial Analysts' Information Environment. Journal of Business Finance \& Accounting, 41, 328-362. http://dx.doi.org/10.2139/ssrn.2267203

Hung, k., Cheng, H.W., Chen, S.S., \& Huang, Y.C. (2013). Factors that affect credit rating: An application of ordered probit models. Romanian journal of economic forecasting, 4, 94-108.

Jeff, S., \& Hisateru G., J. (2014). Japan's slow embrace of outside directors. Published in The Asian Lawyer on July.

Jensen, M. C., \& Meckling, W. H. (1976). Theory of The Firm: Managerial Behavior, Agency Costs and Ownership Structure. Journal of Financial Economics, 3, 305-360. http://dx.doi.org/10.1016/0304-405X(76)90026-X

Jensen, M.C., \& Kevin J.M. (1990). Technical Appendix: How We Estimate CEO Pay for Performance. (Courtesy of Kevin Murphy). 
Kennedy, P. (1985). A guide to econometrics (2nd ed.). Cambridge, C: The MIT Press.

Klein, L., O'Brien, T., \& Peters, S. (2002). Debt vs. equity and asymmetric information: A Review. Financial Review, 37, 317-350. http://dx.doi.org/10.1111/1540-6288.00017

Kor, Y.Y., \& Sundaramurthy, C. (2009). Experience based human capital and social capital of outside directors. Journal of Management, 35, 981-1006. http://dx.doi.org/10.1177/0149206308321551

Lawrence, J. W. (2013). Credit Rating Agencies: An Overview. Annual Review of Financial Economics, 5, 93-122. http://dx.doi.org/10.1146/annurev-financial-110112-120942

Lee, H., Mande, V., \& Son, M. (2008). A comparison of reporting lags of multinational and domestic firms. Journal of International Financial Management and Accounting, 19, 28-56. http://dx.doi.org/10.1111/j.1467-646X.2008.01015.x

Lehn, K., Sukesh, P., \& Zhao, M. (2004). Determinants of the size and structure of corporate boards: 1935-2000. Working Paper, Katz Graduate School of Business.

Lorsch, J. W., \& MacIver, E. (1989). Pawns or Potentates: The Reality of America's Corporate Boards. Boston: Harvard Business School Press.

Merton, R. C. (1974). On the pricing of corporate debt: the risk structure of interest rates. Journal of Finance, 29, 449-470. http://dx.doi.org/10.1111/j.1540-6261.1974.tb03058.x

Morck, R., Shleifer, A., \& Vishny, R. (1988). Management ownership and market valuation: An empirical analysis. Journal of Financial Economics, 20, 293-315. http://dx.doi.org/10.1016/0304-405X(88)90048-7

Raheja, C. G. (2005). Determinants of board size and composition: A theory of corporate boards. Journal of Financial and Quantitative Analysis, 40, 283-306. http://dx.doi.org/10.1017/S0022109000002313

Sah, R., \& Stiglitz, J. (1991). The quality of managers in centralized versus decentralized organizations. Quarterly Journal of Economics, 106, 289-295. http://dx.doi.org/10.2307/2937917

Sengupta, P. (1998). Corporate disclosure quality and the cost of debt. Accounting Review, 73, 459-474.

Shleifer, A., \& Vishny, R. (1986). Large shareholders and corporate control. Journal of Political Economy, 94, 461-488. http://dx.doi.org/10.1086/261385

Standard \& Poor's. (2002). Standard \& Poor's Corporate Governance Scores: Criteria, Methodology and Definitions, New York. McGraw-Hill Companies, Inc.

Upadhyay, A.D. (2015). Board Size, Firm Risk and Equity Discount. The Journal of Risk and Insurance, 82, 571-599. http://dx.doi.org/10.1111/jori.12033

Yang, C.W., \& Raehsler, R.D. (2005). An Economic Analysis on Intermediate. Journal for Economic Educators, 5, 1-11. 


\section{Macrothink}

Asian Journal of Finance \& Accounting ISSN 1946-052X 2016, Vol. 8, No. 1

Yarmack, D. (1996). Higher market valuation of companies with a small board of directors. $\begin{array}{llll}\text { Journal of financial economics, } & 40, & 185-211 .\end{array}$ http://dx.doi.org/10.1016/0304-405X(95)00844-5

Yaron, J., \& Manos, R. (2010). Information Transparency and Agency Costs in the Microfinance Industry: The Adequacy of the Operational Self-Sufficiency Index. Review of Market Integration, 2, 87-99. http://dx.doi.org/10.1177/097492921000200106 